\title{
PKM KELOMPOK USAHA PEMBUAT TAHU DAN TEMPE
}

\author{
Subur $^{1}$, Sri Murtatik ${ }^{2}$ dan Tri Siswantini ${ }^{3}$ \\ ${ }^{1}$ Program studi Akuntansi, FakultasEkonomi dan Bisnis,UPN',Veteran"Jakarta \\ Email: assuburfh@gmail.com \\ ${ }^{2}$ Progiam Studi Manajemen, Fakultas Ekonomi dan Bisnis , UPN "Veteran" Jakarta \\ Email: srimurtatik_fe@yahoo.co.id \\ ${ }^{3}$ Program Studi Manajemen, Fakultas Ekonomi dan Bisnis, UPN "Veteran” Jakarta \\ Email: tinindaru62@gmail.com
}

\begin{abstract}
ABSTRAK
Minat warga RW 04 Kelurahan Krukut Kecamatan Limo Depok terhadap pengembangan usaha pembuatan tahu dan tempe untuk menambah volume produksi dan pasar penjualan produk mereka sangat tinggi. Mereka masih terfokus hanya pada proses peningkatan produksi dan penjualan tahu dan tempe sebanyak-banyaknya, sedangkan masalah yang berkaitan dengan pembukuan tidak diperhatikan. Banyak juga yang beranggapan jika selama usaha dikerjakan sendiri, uang tidak akan pergi kemana-mana dan menganggap bahwa pembukuan membuat mereka menjadi makin rumit dan makan waktu dalam mengelola usahanya. Melalui metode ceramah dan praktek langsung yang dilakukan oleh para pengabdi untuk mengubah pemahaman mereka bahwa pembukuan bukanlah sesuatu yang menyusahkan dan menambah pekerjaan saja, tetapi pembukuan dapat mengontrol perkembangan usaha yang sedang berjalan dan perkembangan usaha selanjutnya. Dengan pembukuan kita akan mengetahui seberapa untung atau rugi yang dialami usaha yang sedang berjalan. Evaluasi dari kegiatan ini adalah menggunakan kuesioner sebelum dan sesudah melaksanakan abdimas, hasil jawaban didapat meningkatnya pemahaman para peserta abdimas terhadap manfaat dari pembukuan (90\%), meningkatnya keyakinan para peserta abdimas bahwa bisnis bisa berkembang dengan melakukan pembukuan (80\%) dan peserta abdimas menghendaki adanya kegiatan abdimas dilakukan kembali dengan tema yang berbeda, sesuai dengan kebutuhan selanjutnya

Kata kunci: Pelatihan, Pembukuan Sederhana
\end{abstract}

\section{PENDAHULUAN}

Program pengabdian pada masyarakat merupakan salah satu kegiatan yamg wajib dilaksanakan oleh dosen Fakultas Ekonomi Universitas pembangunan Nasional "Veteran" Jakarta ,sebagai bentuk aplikasi Tri Darma Perguruan Tinggi yang meliputi kegiatan pendidikan dan pengajaran,penelitian dan Pengabdian pada masyarakat Program pengadian pada masyarakat dapat dilakukan secara perorangan maupun kelompok ,dengan melibatkan masyarakat yang bertujuan untuk meningkatkan wawasan pengetahuan dan pemahaman melalui kegiatan penyuluhan serta monitoring .

UPN "Veteran" Jakarta sebagai perguruan tinggi diharapkan dapat memberikan kontribusi positip bagi masyarakat sekitarnya. Salah satu fokus pengamatan yang kami lakukan terhadap masyarakat sekitarnya.Salah satu fokus pengamatan yang kami lakukan terhadap masyarakat sekitar ,salah satunya yang terletak dikelurahan krukut Kecamatan Limo Kota Depok,Khususnya warga yang berada diwilayah RW 04 .Warga di wilayah ini sebagian besar terdiri dari penduduk asli dan sebagian lainnya adalah pendatang.

Bulan Juni 2012, kami Dosen pengabdi UPN "Veteran" Jakarta memberikan pembinaan sebagai pelaksanaan darma ketiga dari Tri Darma Perguruan Tinggi dengan tema "Pendampingan Kelayakan Usaha Pabrik tahu Wilayah Kelurahan Krukut Limo Depok.” Dampak dari kegiatan tersebut, banyak warga mulai tertarik melakukan sesuatu kegiatan usaha produktif untuk bisa mendapatkan tambahan penghasilan guna menunjang kebutuhan ekonomi rumah tangganya. 
Dari hasil observasi awal terlihat para pengusaha tahu dan tempe lebih fokus pada proses produksi, jualan sebanyak-banyaknya, sedangkan pembukuan tidak diperhatikan. , banyak juga yang beranggapan jika selama usaha dikerjakan sendiri, uang tidak akan pergi kemana-mana. Kami mencoba memberikan satu pemahaman bahwa pembukuan sebenarnya bukan masalah yang sulit , pada dasarnya, untuk pemula ada beberapa poin yang harus dicatat atau dibuat, yakni: buku pengeluaran, segala macam pengeluaran di tulis di buku ini; buku pemasukan, segala macam pemasukan di tulis di buku ini; buku arus kas, laporan laba rugi hal ini sangat penting untuk dicatat agar kita bisa mengetahui saldo akhir yang dimiliki; buku catatan stok, digunakan untuk memudahkan mengetahui stok barang yang habis dan masih ada; buku Inventaris barang, berfungsi untuk mencacat dan berguna untuk mengetahui inventaris barang yang kita miliki sejak dari awal usaha, contohnya: penggorengan, tungku ,dsb yang miliki; buku laba rugi, berfungsi untuk membantu dan mengetahui seberapa besar keuntungan atau kerugian usaha yang dijalani selama ini . Setelah itu para pengusaha tahu dan tempe tertarik akan pelatihan tentang pembukuan sederhana tersebut sehingga meminta kami para Dosen memberikan pengetahuannya tentang pembukuan sederhana ini.

Diharapkan melalui kegiatan ini warga setempat mulai memahami dan menyadari pentingnya pembukuan dalam usahanya.,kemudian berani dan mampu memulai usahanya dengan melakukan pembukuan sederhana unuk mendapatkan penghasilan yang lebih baik guna menunjang kebutuhan Ekonomi rumah tangganya.

\section{TINJAUAN PUSTAKA}

Kewirausahaan merupakan suatu konsep pembelajaran yang terpadu yang dirancang khusus untuk mempelajari konsep, strategi, taktik, dan pengetahuan mengenai cara memulai usaha, serta mengubah pola pikir dan paradigma mengenai kewirusahaan.

Saat ini persaingan di dunia kerja semakin ketat dan pengangguran di Indonesia juga semakin banyak. Hal ini ditambah lagi dengan semakin banyak perusahaan yang melakukan pemutusan hubungan kerja (PHK), mempensiunkan karyawan-karyawannya secara dini, dan bahkan menutup atau atau merelokasikan usahanya ke tempat lain. Hal itu membuat persaingan para pencari kerja semakin ketat.

Mengandalkan seluruhnya kepada Pemerintah untuk membuka lapangan kerja baru tidaklah mungkin, sementara bangsa kita hanya bisa maju dan berkembang apabila banyak tumbuh wirausahawan-wirausahaan muda yang kreatif dan inovatif.

Indonesia membutuhkan enterpreneurial skill untuk bisa menekan sekecil mungkin tingkat tingkat kemiskinan yang tinggi (absolut). Mengandalkan investor asing untuk membuka lapangan kerja tidaklah cukup, meghimbau kepada perusahaan-perusahaan untuk tidak mem-PHK karyawan atau buruhnya juga sulit diwujudkan.jalan terbaiknya adalah mengandalkan sektor pendidikan untuk mengubah pola pikir masyarakat dari berorientasi mencari kerja menjadi mencetak lapangan kerja sendiri atau menjadi wirausahawan mandiri.

\section{a. Kewirausahaan bertujuan untuk mengurangi pengangguran}

Hendro, Dasar-dasar Kewirausahaan (2011 hlm.5 ) Kewirausahaan (enterpreneuship) bukan merupakan ilmu ajaib yang mendatangkan uang dalam waktu sekejap, melainkan sebuah ilmu, seni dan keterampilan untuk mengelola semua keterbatasan sumber daya, informasi, dan dana yang ada guna mempertahankan hidup, mencari nafkah atau meraih posisi puncak dalam karir. 
Perkembangan prosentasi jumlah wirausahawan di Indonesia tidak begitu cepat. Padahal jumlah wirausahawan yang mandiri dan sukses akan menjadi lokomotif ekonomi Indonesia yang mampu mengatasi tingkat pengangguran pasif dan aktif dan pada akhirnya mampu mengatasi tingkat kemiskinan yang absolut atau permanen.

Bila satu orang menjadi wirausaha, maka kemungkinan ia akan mencari temannya sebagai partner dan mungkin salah satu temannya akan diajak untuk menjadi karyawannya (bekerja kepadanya). Jika $10 \%$ dari penduduk indonesia menjadi wirausahawan, maka yang akan bergabung dengannya bisa menjadi 20\% (satu partner dan satu karyawan). Dengan demikian jumlah pesaing pencari kerja akan berkurang $30 \%$. Seandainya sebagian kecil saja masyarakat berpikiran sama, wirausaha bisa menjadi alternatif untuk mengurangi tingkat pengangguran yang sekarang cukup tinggi.

b. Tujuan dan manfaat kewirausahaan

Dahulu, prestasi dan pendidikan saja sudah cukup untuk menjadi bekal mencari pekerjaan dan bertahan hidup. Namun dewasa ini prestasi dan pendidikan itu masih cukup ? belum tentu. Oleh sebab itu, ada begitu banyak tujuan kewirausahaan yang bisa dimanfaatkan, yaitu :

- Pendidikan saja sudah tidak cukup menjadi bekal untuk masa depan. Dahulu saya berpikir pendidikan saja sudah cukup membuat Indonesia mandiri, tetapi sekarang mengapa tetap saja kita terbelakang ? Ternyata kita tidak hanya cukup menguasai ilmu yang umum saja. Bangsa ini membutuhkan orang-orang yang sanggup mengubah "kesulitan" menjadi "peluang" dan memberikan kontribusi bagi perusahaan" kata Ciputra (sumber : kompas, 3 November 2017)

- Kewirausahaan bisa diterapkan disemua bidang pekerjaan dan kehidupan. Dengan demikian, kewirausahaan sangat berguna sebagai "bekal" masa depan.

- Kewirausahaan bisa menjadi langkah alternatif untuk mencari nafkah dan bertahan hidup

- Agar sukses di dunia kerja atau usaha, tidak cukup orang hanya pandai bicara. Yang dibutuhkan adalah bukti nyata/realitas. Oleh karena itu, kewirausahaan adalah ilmu nyata yang bisa diwujudkan.

- Memajukan perekonomian Indonesia dan menjadi lokomotif peningkatan kesejahteraan dan kemakmuran bangsa Indonesia.

- Meningkatkan pendapatan keluarga dan daerah yang akan berujung pada kemajuan ekonomi bangsa.

- Membudayakan sikap unggul, perilaku positif dan kreatif

- Menjadi bekal ilmu untuk mencari nafkah, bertahan hidup dan berkembang.

c. Kewirausahaan di Indonesia belum berkembang secara maksimal karena pola pikir yang salah.

Para pebisnis muda menganggap bisnis itu coba-coba. Kesuksesan dalam berbisnis itu keberuntungan. Oleh sebab itu mereka nekad, berani, ikut-ikutan tau meniru bisnis orang lain tanpa memahami hakikat dan sejarah bisnis itu terlebih dahulu. Tentu saja bisnis yang bermodalkan ikutikutan atau coba-coba, hampir sebagian besar berujung pada kebangkrutan. Akibat selanjutnya adalah pilihan karir menjadi pebisnis/pengusaha dihindari oleh banyak orang. Hal inilah yang menyebabkan enterpreneurship di Indonesia nyaris tidak berkembang.

Pada umumnya ada dua faktor utama yang menyebabkan enterpreneur-enterpreneur di Indonesia bisa meraih kesuksesan. Faktor-faktor itu adalah :

- Tempaan waktu dan kerja keras yang tidak kenal menyerah

- Modal yang cukup dan terus menerus dikucurkan dana dan akhirnya sukses.

- Usaha para enterpreneur muda itu mati suri atau tidak berkembang. 
Hal ini terjadi karena sistem pendidikan di Indonesia sejak usia dini tidak memperkenalkan kepada para siswa enterpreneurship concept and skill. Begitu pula terjadi di perguruan tinggi.

d. Kewirausahaan adalah kemampuan untuk merangkai dan memberdayakan semua yang anda punyai.

Ketrampilan entrepreneurial adalah mata uang. Sisi yang satu adalah pengetahuan akademis dan prestasi, sisi lainnya adalah kemampuan untuk mengelola, memberdayakan, dan memanfaatkan pengetahuan akademis dalam mengatasi masalah, kesulitan dan tantangan yang dihadapi. Untuk itu, kreativitas dan inovasi berfungsi melengkapi.

Jadi kreatifitas adalah kemapuan mengelola, memberdayakan, dan menggunakan pengetahuan apapun yang kita miliki, informasi, pengalaman, dan ketrampilan lainnya untuk mengatasi kesulitan. Pengetahuan adalah perkakas dan kreativitas adalah cara "memasak" untuk membuat segalanya terselesaikan dengan baik. Kemampuan entrepreneurship adalah penggabungan dari dua sisi kemampuan untuk mengatasi kesulitan dan tantangan bisnis.

Jadi, kemampuan kewirausahaan adalah cara memberdayakan semua pengetahuan yang dimiliki (pengetahuan sumber daya, produksi, IT, Keuangan, dan marketing) dengan kreativitas untuk sukses di bidangnya, baik di dunia pekerjaan maupun wirausaha. Semakin lengkap pengetahuan, semakin banyak nilai pengetahuan yang bernilai yang kita miliki. Konsekuensinya, dalam berkarir kita akan lebih cepat naik ke posisi puncak, (intrapreneurship) atau kewirausahaan perusahaan (top executive) dan di dunia usaha disebut kewirausahaan (entrereneurship).

Menurut Ganjar Isnawan ( 2012 ) Pentingnya membuat pembukuan sederhana Bagi Bisnis dan Usaha kecil..Sebaiknya setiap pengusaha memahami cara pentingnya membuat atau memiliki pembukuan sederhana bagi yang menjalankan usaha maupun bisnis kecil. Hal ini dengan alasan bahwa setiap usaha yang dikerjakan selalu dibutuhkan analisa antara keuntungan yang diperoleh dengan pengeluaran agar usaha yang dijalankan tetap berjalan,sehingga untuk mempermudah dalam melihat arus keuangan tersebut dibutuhkan pembukuan, Pengertian secara umum adalah proses pencatatan yang mengumpulkan semua informasi dan data yang berhubungan dengan laporan keuangan. Resiko yang dapat terjadi apabila dalam setiap usaha tidak dilakukan pencatatan adalah munculnya kecurangan yang berkaitan dengan keuangan.Sehingga pada saat usaha mulai berjalan sebaiknya disertai pula pembukuan yang biasa dilakukan setiap hari dan pada saat akhir tahun dilakukan perhitungan total agar mendapatkan informasi pencapaian hasil dalam setahun. Langkah langkah sedehana yang bisa dilakukan dalam membuat pembukuan bisnis yang sederhana : Memiliki catatan untuk semua transaksi pengeluaran,Catatan untuk semua transaksi pemasukan ,Estimasi Arus Kas,Daftar cacatan Stock, Data dan cacatan semua barang inventaris ,Laporan Laba Rugi.

\section{DISKUSI}

Pelaksanaan abdimas bertempat di balai warga yang berada di Rw 04 ditempuh dengan beberapa langkah antara lain :tahapan persiapan, tahapan pelaksanaan kegiatan yaitu pelatihan tentang pembukuan sederhana dan tahapan evaluasi,

Dalam tahapan pelaksanaan kegiatan diawali dengan tahapan persiapan menentukan khalayak sasaran, kami mengambil Rw 04 dan RW 05 yang berdekatan dengan balai warga. Mereka adalah kelompok usaha tahu dan tempe yang berjumlah 20 orang warga yang sudah memulai usahayang berada di lingkungan Rw 04 dan RW 05, Dari penentuan khalayak sasaran tersebut didapat 20 orang pelaku usaha tahu dan tempe yang sudah memulai usaha sebanya 20 orang dan sisanya 10 orang adalah ibu rumah tangga memiliki semangat wirausaha dan mulai tertarik untuk memulai usaha. 
Tahapan pelaksanaan kegiatan pelatihan membuat pembukuan sederhana dengan susunan acara : pembukaan (menyanpaikan maksud dan tujuan dilaksanakan abdimas), kemudian dilanjutkan dengan pemberian materi dengan metode ceramah dan paparan menggunakan alat bantu Laptop dan proyektor, kemudian dilanjutkan dengan praktek langsung membuat pembukuan sederhana dibantu oleh 2 (dua) orang mahasiswa Fakultas Ekonomi dan bisnis, dimana diharapkan setelah pelatihan peserta dapat mengatur usahanya dan melihat apakah bisnis yang dijalaninya itu berkembang atau tidak.

Materi pelatihan disampaikan dalam bentuk power point yang dibagikan kepada peserta sesuai jumlah yang hadir .Dengan dukungan laptop, projector dan alat peraga lainnya pengabdi dapat menyampaikan materi dan dilanjutkan dengan praktek langsung membuat pembukuan sederhana.

\section{HASIL DAN PEMBAHASAN}

Pelaksanaan kegiatan Pengabdian kepada masyarakat dengan judul” PKM Kelompok tahu dan tempe di Lingkungan kelurahan Krukut Kecamatan Limo Depok . Dari Pengabdian tersebut diperoleh hasil yang cukup baik.,kami mengambil Kegiatan Masyarakat ini sudah sesuai dengan rencana jadwal yang telah ditetapkan bersama .Pelaksanaan kegiatan program pengabdian kepada masyarakat dilaksanakan pada bulan Agustus 2018 s.d November 2018.

Sebelum kegiatan pengabdian Kepada masyarakat ini dilakukan terlebih dahulu penentuan khalayak sasaran yaitu kelompok usaha tahu dan tempe di desa Krukut ,Depok berjumlah 30 (tiga puluh ) orang .Mereka adalah kelompok usaha yang berada di Rw $04 \mathrm{Rw} 05$.Setelah Khalayak sasaran sudah diketahui kami membuat kesepakatan dengan peserta agar pelaksanaan tidak mengganggu kegiatan mereka dan diperoleh kesepakatan abdimas dilakukan hari Sabtu Malam minggu tanggal 25 Agustus 2018.Sebelum pelaksanaan dilakukan pembagian kuesioner tentang pemahaman pembukuan sederhana .

Pada tanggal 25 Agustus 2018 dilaksanakan sosialisasi dan pelatihan pembukuan kepada pelaku usaha tahu dan tempe untuk menambah penghasilan ,yang meliputi penjelasan tentang apa yang dimaksud dengan pembukuan ,penjelasan tujuan dan bagaimana manfaat dan pentingnya membuat pembukuan dalam usaha.Selanjutnya dilakukan pelatihan secara langsung membuat pembukuan sederhana.Sebelum pelaksanaan dilakukan evaluasi ,peserta abdimas mengisi kuesioner yang telah disiapkan oleh tim pengabdi sebanyak 20 (duapuluh) orang berdasarkan khalayak sasaran yang telah ditetapkan .Pada tahap berikutnya akan diadakan pelatihan yang kedua untuk mengulang dan melanjutkan materi yang sama . Kemudia pada pertemuan ke dua tim melakukan post test ,untuk mengetahui seberapa besar pemahaman mereka setelah diadakan pelatihan tentang membuat pembukuan sederhana hasil dari pre test sebelum pelaksanaan pelatihan dimulai dapat diliat dalam tabel berikut : 
Tabel 1. Hasil Jawaban peserta pelatihan sebelum pelatihan dilaksanakan

\begin{tabular}{|l|l|c|c|c|c|c|c|c|c|}
\hline No & \multicolumn{1}{|c|}{ PERTANYAAN } & & & & & & & & \\
\hline 1 & SJ & $\%$ & S & $\%$ & KS & $\%$ & TS & $\%$ \\
\hline 2 & $\begin{array}{l}\text { Mengetahui yang dimakssud } \\
\text { dengan pembukuan }\end{array}$ & 0 & 0 & 2 & 10 & 2 & 10 & 16 & 80 \\
\hline 3 & $\begin{array}{l}\text { Mengetahui manfaat pembukuan } \\
\text { Pernah membuat pembukuan } \\
\text { Sebelumnya }\end{array}$ & 0 & 0 & 2 & 10 & 3 & 20 & 15 & 75 \\
\hline 4 & $\begin{array}{l}\text { Pembukuan itu menyusahkan dan } \\
\text { hanya menambah pekerjaan }\end{array}$ & 18 & 90 & 1 & 5 & 1 & 5 & 0 & 0 \\
\hline 5 & $\begin{array}{l}\text { Setelah mengikuti pelatihan } \\
\text { mampu membuat pembukuan } \\
\text { sederhana }\end{array}$ & 10 & 50 & 8 & 40 & 1 & 5 & 1 & 5 \\
\hline 6 & $\begin{array}{l}\text { Merasa yakin bahwa bisnis bisa } \\
\text { berkembang dengan melakukan } \\
\text { pembukuan. }\end{array}$ & 1 & 5 & 2 & 10 & 15 & 75 & 2 & 10 \\
\hline
\end{tabular}

Dari hasil pre test menunjukan bahwa sebelum dilaksanakan pelatihan bagaimana membuat pembukuan sederhana untuk pelaku usaha tahu dan tempe sebanyak 16 0rang atau $80 \%$ menjawab tidak setuju artinya mereka para pengusaha tahu dan tempe kurang mengetahui apa yang dimaksud dengan pembukuan sederhana.sebanyak 2 orang menyatakan kurang setuju atau $10 \%$ kurang mengetahui pembukuan, dari tabel tersebut ada $10 \%$ yang sudah mengetahui pembukuan sederhana.

Dari tabel dapat di simpulkan juga bahwa yang mengetahui manfaat dari pembukuan hanya 2 0rang atau $10 \%$,dan sisa menjawab kurang setuju 20\%,menjawab tidak setuju $75 \%$.

Hasil Yang ditunjukan dalam tabel pernyataan apakah mereka pernah membuat pembukuan sebelumnya ,hanya 1 orang atau sekitar $5 \%$ sisanya 95\% belum pernah melakukan.Dari pernyataan pembukuan menyusahkan dan menambah pekerjaan sebanyak 18 orang atau $90 \%, 1$ orang atau $5 \%$ menjawab setuju dan 1 orang menjawab kurang setuju atau 5\%. Menurut para pengusaha tahu dan tempe bahwa pembukuan itu menyusahkan dan menambah pekerjaan dalam tabel dapat dilihat bahwa $90 \%$ menyatakan bahwa pembukuan menyusahkan dan menambah pekerjaan, dari pernyataan dapat diliat bahwa sekitar $50 \%$ menjawab setelah mengikuti pelatihan mampu membuat pembukuan dan sisanya merasa kurang mampu membuat pembukuan, Para pengusaha tahu dan tempe kurang yakin bahwa bisnis bisa berkembang dengan adanya pembukuan sekitar $5 \%$ yang menjawab sangat setuju $10 \%$ setuju,kurang setuju $75 \%$ dan tidak setuju $10 \%$. Setelah pelatihan di bagikan kuesioner untuk mengetahui perkembangan setelah diadakan pelatihan .hasilnya dapat dilihat dalam tabel berikut : 
Tabel 2. Hasil Jawaban peserta setelah pelatihan dilaksanakan

\begin{tabular}{|c|c|c|c|c|c|c|c|c|c|}
\hline No & PERTANYAAN & & & & & & & & \\
\hline 1 & $\begin{array}{c}\text { Mengetahui yang dimaksud } \\
\text { dengan pembukuan }\end{array}$ & 18 & 90 & 2 & $\begin{array}{c}1090 \\
\%\end{array}$ & 0 & 0 & 0 & 0 \\
\hline 2 & Mengetahui manfaat pembukuan & 20 & 100 & 0 & 0 & 0 & 0 & 0 & 0 \\
\hline 3 & $\begin{array}{c}\text { Pembukuan itu menyusahkan dan } \\
\text { hanya menambah pekerjaan }\end{array}$ & 2 & 10 & 2 & 10 & 5 & 25 & 11 & 55 \\
\hline 4 & $\begin{array}{c}\text { Setelah mengikuti pelatihan } \\
\text { mampu membuat pembukuan } \\
\text { sederhana }\end{array}$ & 15 & 75 & 5 & 25 & 0 & 0 & 0 & 0 \\
\hline 5 & $\begin{array}{c}\text { Merasa yakin bahwa bisnis bisa } \\
\text { berkembang dengan melakukan } \\
\text { pembukuan. }\end{array}$ & 16 & 80 & 4 & 20 & 0 & 0 & 0 & 0 \\
\hline 6 & $\begin{array}{c}\text { Prosedur yang diberikan tidak } \\
\text { berbelit-belit }\end{array}$ & 16 & 80 & 4 & 20 & 0 & 0 & 0 & 0 \\
\hline 7 & $\begin{array}{c}\text { Ketrampilan team dalam } \\
\text { penyampaian materi mampu } \\
\text { menjelaskan secara jelas. }\end{array}$ & 17 & 85 & 3 & 15 & 0 & 0 & 0 & 0 \\
\hline
\end{tabular}

Dari tabel diatas dapat kita lihat hasil jawaban pernyataan bahwa mengetahui yang dimaksud dengan pembukuan dari seluruh peserta sebanyak 20 orang $100 \%$ menyatakan sangat setuju ,untuk peryataan mengetahui manfaat pembukuan sebanyak $100 \%$ menjawab mengetahui.Untuk jawaban pembukuan menyusahkan sebanyak $10 \%$ atau sebanyak 2 Orang.

Dari 20 Peserta yang menjawab setelah mengikuti pelatihan mampu membuat pembukuan sederhana sebanyak 15 orang sangat setuju atau $75 \%$ yang setuju $25 \%$.,sedangkan yang menjawab merasa yakin bahwa bisnis bisa berkembang dengan melakukan pembukuan sebanyak $80 \%$ sangat setuju dan $20 \%$ setuju. Dari pernyataan bahwa tem memberikan pelatihan tidak berbelit-belit sebanyak $80 \%$ sangat setuju dan $20 \%$ setuju,untuk pernyataan Ketrampilan team dalam penyampaian materi ,mampu menjelaskan secara jelas sebanyak $85 \%$ sangat setuju dan sisanya $15 \%$ setuju.I

Hasil Analisa setelah diadakan pelatihan menunjukan hasil yang berbeda dengan sebelum dilaksaanakan pelatihan .Ini menunjukan bahwa pelaku usaha tahu dan tempe sudah mempunyai pemahaman dan ketrampilan dalam pembukuan sederhana .

Apabila dilihat dari apakah mereka mengetahui manfaat dari pembukuan, hanya 2 orang atau $10 \%$ saja mereka menjawab setuju, artnya hanya $10 \%$ itulah yang benar benar tahu manfaat melakukan pembukuan apabila mereka menjalankan usaha, sedangkan sisanya sebanyak 10 orang atau $50 \%$ menjawab kurang setuju dan 8 orang atau 40\% menyatakan tidak setuju, artinya $90 \%$ dari ibu rumah tangga yang baru memulai ini kurang pengetahuan terhadap manfaat dan pentingnya melakukan pembukuan.

Hasil jawaban dari pernyataan bahwa apakah mereka pernah membuat pembukuan sebelumya, hanya ada 1 orang atau $5 \%$ saja yang menjawa setuju, sisanya 19 orang atau $95 \%$ tidak pernah membuat pembukuan sebelumnya. Dari pernyataan bahwa pembukuan itu menyusahkan dan hanya menambah pekerjaan, sebanyak 18 orang atau $90 \%$ menjawab setuju , 1 orang atau $5 \%$ menjawab kurang setuju 
dan 1 orang atau $5 \%$ menjawab tidak setuju, artinya hanya 5\% saja yang merasa bahwa pembukuan itu tidak menyusahkan dan hanya menambah pekerjaan.

Dalam pernyataan bahwa merasa yakin bahwa bisnis bisa berkembang dengan melakukan pembukuan, yang menjawab kurang setuju adalah jawaban terbanya yaitu 19 orang atau $95 \%$ artinya mereka tidak yakin kalau pembukuan itu dapat mengarahkan mereka untuk dapat memantau perkembangan bisnis atau usaha yang sedang mereka jalankan.

Setelah dilakukan pendampingan pelatihan membuat pembukuan sederhana untuk usaha tahu dan tempe yang kedua terlihat perkembangan yang sangat sigifikan ( $95 \%$ ) terhadap pernyataan mengetahui apa yang dimaksud dengan pembukuan dan pernyataan manfaat dari pembukuan,disini dapat diambil kesimpulan bahwa kami para pengabdi telah berhasil memberikan pengetahuan terhadap para peserta abdimas dalam memahami yang dimaksud dengan pembukuan serta manfaat pembukuan untuk segala jenis usaha atau bisnis .para pelaku uasaha tahu dan tempe menyadari bahwa pembukuan itu sesuatu yang tidak menyulitkan tetapi pembukuan itu adalah sebenarnya pencatatan yang sangat diperlukan untuk pelaku usaha. Para pengusaha juga yakin bahwa bisnis dapat berkembang dengan mengadakan pembukuan.

\section{KESIMPULAN}

Dengan mengadakan pelatihan dan pendampingan pembukuan sedernaha bagi usaha pabrik tahu dan tempe kemudian kita mengevaluasi berupa penyebaran kuesioner sebelum dan sesudah pengabdian terlihat bahwa kami para pengabdi berhasil memberikan pemahaman kepada peserta abdimas bahwa pembukuan bermanfaat untuk melihat perkembangan usaha tahu dan tempe yang kita jalankan terlihat dari meningkatnya pengetahuan masing masing sebesar $95 \%$ terhadap pernyataan mengetahui apa yang dimaksud dengan pembukuan dan manfaat pembukuan. Dalam mengubah pemikiran dan prepsepsi dari para pelaku usaha tahu dan tempe bahwa pembukuan menyusahkan dan hamya menambah pekerjaan menurut mereka pembukuan itu sangat penting dan sangat diperlukan untuk melihat dan mengontrol perkembangan usaha yang sedang kita jalankan .

Abdimas yang kita lakukan dan materi yang kita berikan cukup dapat memotivasi mereka untuk memulai membuat pembukuan dalam usaha yang sedang berjalan,dengan pemahaman tersebut $95 \%$ menyatakan setuju. Sedangkan dalam menyakinkan para pelaku usaha tahu perkembangan usaha yang sedang kita jalankan terbukti dengan meningkatnya sebesar keyakinan dari para pelaku usaha yang sebelumnya $5 \%$ menjadi $80 \%$ menyatakan sangat setuju.

Secara keseluruhan tujuan kegiatan ini dapat tercapai karena pengabdian yang kita laksanakan cukup memotivasi mereka untuk membuat pembukuan dalam usaha yang sedang dijalankan. Dalam meyakinkan para pelaku usaha tahu dan tempe bahwa usaha bisa berkembang dengan melakukan pembukuan berhasi meningkatkan pemahaman sebesar $80 \%$. Para peserta mengharapkan bahwa abdimas dapat dilakukan kembali dengan tema yang berbeda .

\section{DAFTAR PUSTAKA}

Ganjar ,Isnawan ,2012, Akuntansi Praktis Untuk UMKM,Penerbit : Laskar Aksara ,jakarta Hendro ,2011,Dasar-dasar Kewirausahaan,Panduan Bagi Mahasiswa Untuk mengenal Memahami,dan memasuki Dunia Bisnis,Airlangga

Ikatan Akuntansi Indonesia ,Standar Akuntansi Keuangan Untuk Entitas Tanpa Akuntabilitas Mubarok Abdulah ,Faqihudin,2011 ,Pengelolaan Keuangan Untuk Usaha kecil dan menengah

Suluh Media ,Tangerang

Publik (ETAP) 2009,penerbit : dewan Standar Akuntansi Keuangan, Jakarta.

Rhenald, Kasali ,dkk 2010 , Modal Kewirausahaan,Yayasan Rumah Perubahaan,Jakara 
Rahmady ,2006,Alternatif Menjadi Kaya,Badan Penerbit Mahardika

Suryana, 2006. Kewirausahaan, Pedoman Praktis, Kiat dan Proses menuju Sukses. Edisi Revisi. Salemba Empaat Jakarta

Tambunan,Tulus ,2012,Usaha Mikro Kecil dan Menengah Di Indonesia ,Penerbit LP3ES ,Jakarta 